\title{
Developing a groundwater vulnerability map for unconventional oil and gas extraction: a case study from South Africa
}

\author{
Surina Esterhuyse ${ }^{1}$ (D)
}

Received: 15 May 2017/ Accepted: 29 August 2017/Published online: 7 September 2017

(c) The Author(s) 2017. This article is an open access publication

\begin{abstract}
Some of the most important issues surrounding unconventional oil and gas (UOG) extraction are the possible impacts of this activity on potable groundwater resources and how to minimise and mitigate such impacts. A groundwater vulnerability map for UOG extraction has been developed as part of an interactive vulnerability map for South Africa in an effort to address such concerns and minimize possible future impacts linked to UOG extraction. This article describes the development of the groundwater theme of the interactive vulnerability map and highlights important aspects that were considered during the development of this map, which would also be of concern to other countries that may plan to embark on UOG extraction. The policy implications of the groundwater vulnerability map for managing UOG extraction impacts is also highlighted in this article.
\end{abstract}

Keywords Unconventional oil and gas · Impact . Groundwater · Vulnerability map · South Africa · Policy implications

\section{Introduction}

Unconventional oil and gas (UOG) extraction has various biophysical and socio-economic impacts, ranging from positive to negative. One of the resources on which UOG extraction can have a severe impact is groundwater resources. Impacts from UOG extraction may range from

Surina Esterhuyse

esterhuyses@ufs.ac.za

1 Centre for Environmental Management, University of the Free State, P.O. Box 339, Bloemfontein, South Africa aquifer dewatering during UOG extraction (Esterhuyse et al. 2016a; Freyman 2014; Grant and Chrisholm 2014), aquifer deformation (Lechtenböhmer et al. 2011; Zoback et al. 2010; NRC 2012a), as well as aquifer contamination (Esterhuyse et al. 2016a; Vengosh et al. 2014; Williams et al. 2012). In some cases, these impacts may be irreversible, such as where aquifer contamination cannot be cleaned up due to economic or physical reasons. Physical clean-up may be impossible, for instance, when certain organic contaminants that absorb to soil particles cannot be effectively removed from aquifer systems (NRC 2012b; GAO 2010), due to the fact that sorption processes are spatially heterogeneous, nonlinear, and potentially limited by solute diffusion to sorbent material located within the interior of soil particles. Excessive clean-up costs can also hamper effective rehabilitation. Clean-up costs, which is estimated to be in the region of $\$ 110-127$ billion (but which is likely to be a gross underestimate), remain a significant technical and institutional challenge at approximately 126,000 organically contaminated sites across the USA (NRC 2012b).

If groundwater resources are to be properly protected, it is important that such impacts should be minimised and managed even before exploration for UOG resources starts. Baseline monitoring of groundwater resources and the development of baseline vulnerability maps that show the location of sensitive groundwater resources are important tools that may assist governments in their decisions to allow, or not allow, UOG extraction in certain fragile areas and may aid in the regulation of UOG extraction in sensitive aquifers.

Most international vulnerability maps to manage and minimize impacts from UOG extraction have focused on groundwater resources (Russack 2012; Rivard et al. 2014) These maps identified vulnerability to water contamination 
from current fracking operations in areas where UOG resources are already being extracted. The groundwater vulnerability map of the South African case study has however been developed before UOG extraction is to start in South Africa; and thus adheres to the precautionary principle as reflected in international law, that aims to prevent environmental harm when there is scientific uncertainty about such harm.

Developing natural resource baseline vulnerability maps would ensure better protection of natural resources by providing information on sensitive groundwater resources before UOG extraction starts. This information can also directly feed into an adaptive management plan by reducing uncertainty in our understanding of the effects of UOG extraction and risks to natural resources and humans (Brittingham et al. 2014). Baseline monitoring and mapping would also provide an impartial scientific base to support the sustainable use of resources in UOG extraction areas and will state various data shortcomings that may hamper proper natural resource protection. Countries that are still planning to embark on UOG extraction thus have the unique opportunity to address data needs and perform crucial baseline vulnerability mapping before UOG extraction starts.

This paper discusses the development of the groundwater theme of the South African UOG vulnerability map, where UOG extraction may become a possibility in the future, but is not yet being extracted. This map was developed specifically to assist regulators in assessing vulnerability on a larger spatial scale by considering the possible effects of UOG development across provincial boundaries and themes (e.g. they can compare vulnerability of groundwater and socio-economic factors for a specific region).

\section{Method}

For the development of the groundwater theme of the interactive UOG vulnerability map, sensitivity indicators that would indicate groundwater aspects that are sensitive to UOG extraction were identified using the "impacts" method (Harvey et al. 2009, 2011). Using a normative approach (which entails using expert knowledge based on subjective individual or collective expert opinion), groundwater experts were used to identify the relevant groundwater sensitivity indicators for UOG extraction. Although this approach requires time and resources and is limited in its application and transferability to other regions or case studies, the integration of expert knowledge may increase the acceptability of the results (by encouraging transparency, credibility, and pragmatism). Integrating expert knowledge during indicator development is also key to identifying relevant vulnerability indicators (Harvey et al. 2011; Nardo et al. 2005).

The groundwater experts who participated in the study had to have knowledge of UOG extraction by means of hydraulic fracturing, or had to be involved in research related thereto. In some cases, not all the participants could comply with this requirement, highlighting how new this field of research is in South Africa. To address this issue, possible impacts on groundwater resources that may emanate from exposure to UOG extraction by means of hydraulic fracturing, based on the "issues/impacts concept" (Harvey et al. 2009, 2011; Preston and StaffordSmith 2009), were presented to the experts during the first questionnaire. This information served as a conceptual framework to guide the development of indicators and to help experts understand the links between indicators (Brown 2009). It was expected that presenting this information would avoid the selection of a mix of indicators with no clear rationale for their selection. This information was used by experts to assess the appropriateness of indicators that were proposed for mapping various sensitivity indicators in relation to possible impacts.

For the development of the groundwater theme, 14 experts were approached and 12 participated in the indicator selection and classification. Experts ranged from groundwater specialists in academia (2 respondents) to consultancy (7 respondents), and government (2 respondents). One hard rock specialist also contributed to the indicator selection and classification. The years of experience of the experts ranged between 12 and 38 years, with an average of 25 years' experience. Experts were chosen mainly based on their involvement in research or consulting related to UOG extraction, and seven of the contributing respondents complied with this requirement. Four respondents had detail knowledge on governance aspects, five respondents possessed in-depth knowledge on geological structures, and one respondent had extensive knowledge of GIS. Due to the sensitive and politicised nature of UOG extraction in South Africa, and in order to adhere to ethical research practices (Maree et al. 2010), all responses are treated anonymously.

Two questionnaires were used during the mapping process to engage with the experts for identifying indicators, classifying the base-layer vulnerabilities, and identifying important additional overlay information. In "Questionnaire 1", the exploratory indicator identification questionnaire, experts had to indicate the appropriateness of a list of possible indicators that could indicate groundwater vulnerability to UOG extraction on a likert scale that ranged from 1 to 10 . The indicators that experts had to assess for suitability in Questionnaire 1, included the South African composite aquifer vulnerability (DWAF 2005), which is based on DRASTIC (Aller et al. 1987), geological 
features such as dolerite dykes, kimberlites and diatremes, faults and shear zones, folded strata (CGS 2013), electrical conductivity (EC) to indicate groundwater quality (DWAF 2005), and aquifer yield to indicate groundwater volumes (DWAF 2005). Each of the scale-based questions had a follow-up question in which key informants had to supply reasons for their answers on the scale-based questions. The experts also had to suggest additional indicators where applicable. The results from the scale-based questions were analysed quantitatively in the Statistical Package for the Social Sciences (SPSS) and the descriptive statistics are presented in Table 1. The qualitative feedback in Questionnaire 1 (where experts had to motivate their ratings of the appropriateness of the indicators) were analysed thematically by identifying the main themes that emerged from their feedback (see Table 1).

During the indicator identification phase, experts were also asked to indicate data availability if they indicated the use of alternative indicators. The selected indicators which the experts had to assess for suitability had to be currently available, nationally acceptable, regional-scale indicators for which data was available for the whole country. Localscale indicators were not considered because they do not contain the same level of information throughout the country and because local-scale conditions should be interpreted differently for each site. It was decided to map vulnerability for the entire country since infrastructure development to capture and transport oil or gas as well as store and/or transport wastewater and waste may influence areas outside the target UOG extraction zones.

The expert answers from Questionnaire 1 were used to identify sensitivity indicators to map groundwater vulnerability to UOG extraction. Based on the expert feedback from Questionnaire 1, relevant base-layer indicators (that were to be classified into 5 classes of vulnerability) and overlay indicators were identified for the groundwater vulnerability map. Overlay indicators convey important additional information but did not comply with the study requirements of serving as a base layer (for instance, it did not cover the whole of South Africa). Areas where legislation prescribes how certain activities may take place, where activities are prohibited by law, or where assessment or protection zones are required have also been mapped as overlay indicators.

The base-layer indicator classification of the groundwater vulnerability map and confirmation of the groundwater-related overlay indicators was done via the second round of questionnaires. Based on expert input, the baselayer indicator was then classified into five classes of vulnerability (very low, low, medium, high, and very high). Overlay indicators did not require weighting and were included as overlays on the base maps in the browser.

\section{Results and discussion}

\section{Indicator selection}

The data received from the first set of questionnaires on indicator selection were analysed and interpreted by quantitatively analysing the scale-based answers by using descriptive statistics as well as qualitatively analysing the expert responses where experts explained their ratings of the indicators, by using thematic analysis. Although descriptive statistics are useful for helping to identify indicators, it cannot be used as a sole measure and qualitative thematic analyses of expert opinions which were also used for final indicator selection. Thematic analyses revealed a few expert concerns with specific indicators that guided the inclusion or exclusion of indicators. The results of the basic analysis for the first round of questionnaires can be seen in Table 1 .

\section{Base-layer indicator}

The South African DRASTIC vulnerability map that was developed during the Groundwater Resource Assessment II (GRAII) (DWAF 2005) was selected as the base layer for the UOG extraction groundwater vulnerability map. DRASTIC, developed in the USA with the support of the US Environmental Protection Agency (EPA), was designed to be a standardised system for evaluating the groundwater vulnerability for a variety of land areas (Wang et al. 2011) and usually represents regional groundwater vulnerability. It assesses aquifer sensitivity based on seven hydrological parameters that include the depth to groundwater, recharge rates, aquifer material, soil composition, land slope, vadose zone materials and saturated hydraulic conductivity (Aller et al. 1987). Each hydrological parameter is assigned a constant as weight (Aller et al. 1987). Although the indicator did not receive unambiguous support from the experts, many did not take into account the fact that surface activities related to UOG extraction could impact on shallow groundwater quality via surface water/groundwater interaction or on its quantity via extraction for water use during fracking operations. The experts mostly focused very narrowly on the possible deep groundwater quality impact of specifically fracking, while not taking into account possible pollution on the land surface from leaking waste pits, transport accidents, and spillages, amongst others, that may impact on shallow aquifer systems. However, during a recent strategic environmental assessment of shale gas development in South Africa, surface impacts were rated as representing the highest risk to groundwater resources during UOG extraction (Hobbs et al. 2016). This makes the DRASTIC indicator currently 
Table 1 Results from first set of questionnaires to identify indicators

\begin{tabular}{|c|c|c|c|c|c|c|c|c|c|c|c|}
\hline \multirow{2}{*}{$\begin{array}{l}\text { Indicator/data } \\
\text { source }\end{array}$} & \multicolumn{2}{|l|}{$N$} & \multirow[t]{2}{*}{ Mean } & \multirow[t]{2}{*}{ Median } & \multirow[t]{2}{*}{ Mode } & \multirow[t]{2}{*}{ SD } & \multirow[t]{2}{*}{ Min } & \multirow[t]{2}{*}{$\operatorname{Max}$} & \multirow{2}{*}{$\begin{array}{l}\text { Main themes } \\
\text { supporting use of } \\
\text { indicator and/or } \\
\text { data source }\end{array}$} & \multirow{2}{*}{$\begin{array}{l}\text { Main themes not } \\
\text { supporting use of } \\
\text { indicator and/or data } \\
\text { source }\end{array}$} & \multirow{2}{*}{$\begin{array}{l}\text { Indicator } \\
\text { usage in } \\
\text { UOG } \\
\text { extraction } \\
\text { groundwater } \\
\text { vulnerability } \\
\text { map }\end{array}$} \\
\hline & Valid & Missing & & & & & & & & & \\
\hline $\begin{array}{l}\text { Appropriateness } \\
\text { of the } \\
\text { composite } \\
\text { aquifer } \\
\text { vulnerability }\end{array}$ & 11 & 0 & 5.64 & 5.00 & 5.00 & 3.07 & 1.00 & 10.00 & $\begin{array}{l}\text { Relevant to surface } \\
\text { aquifer } \\
\text { contamination, } \\
\text { which will also be } \\
\text { an issue in } \\
\text { unconventional } \\
\text { oil and gas mining } \\
\text { (extraction) }\end{array}$ & $\begin{array}{l}\text { Only relevant to surface } \\
\text { aquifer contamination, } \\
\text { fracking will take place } \\
\text { at much deeper levels }\end{array}$ & $\begin{array}{l}\text { Used as a base } \\
\text { layer. This } \\
\text { indicator } \\
\text { was } \\
\text { classified } \\
\text { into } 5 \\
\text { classes of } \\
\text { vulnerability }\end{array}$ \\
\hline $\begin{array}{l}\text { Appropriateness } \\
\text { of including } \\
\text { dykes as an } \\
\text { indicator }\end{array}$ & 11 & 0 & 8.09 & 9.00 & 10.00 & 2.30 & 4.00 & 10.00 & $\begin{array}{l}\text { Dykes are } \\
\text { appropriate as } \\
\text { they may indicate } \\
\text { zones of higher } \\
\text { transmissivity }\end{array}$ & $\begin{array}{l}\text { Surface outcrop of } \\
\text { dykes, although useful, } \\
\text { may not provide an } \\
\text { indication of } \\
\text { morphology at depth }\end{array}$ & $\begin{array}{l}\text { Used as } \\
\text { overlay. } \\
\text { This } \\
\text { indicator } \\
\text { was } \\
\text { buffered } \\
\text { with a } \\
\text { setback }\end{array}$ \\
\hline $\begin{array}{l}\text { Appropriateness } \\
\text { of including } \\
\text { kimberlites } \\
\text { and diatremes } \\
\text { as an indicator }\end{array}$ & 10 & 1 & 7.40 & 8.00 & 10.00 & 2.67 & 4.00 & 10.00 & $\begin{array}{l}\text { They affect } \\
\text { hydraulic } \\
\text { conductivity (K), } \\
\text { they are known to } \\
\text { penetrate at depth, } \\
\text { may represent } \\
\text { conduits from } \\
\text { depth to surface }\end{array}$ & $\begin{array}{l}\text { May fall outside area of } \\
\text { oil and gas } \\
\text { unconventional mining } \\
\text { (extraction) }\end{array}$ & $\begin{array}{l}\text { Used as } \\
\text { overlay. } \\
\text { This } \\
\text { indicator } \\
\text { was } \\
\text { buffered } \\
\text { with a } \\
\text { setback }\end{array}$ \\
\hline $\begin{array}{l}\text { Appropriateness } \\
\text { of including } \\
\text { faults and } \\
\text { shear zones as } \\
\text { an indicator }\end{array}$ & 11 & 0 & 8.91 & 9.00 & 10.00 & 1.22 & 7.00 & 10.00 & $\begin{array}{l}\text { These may be } \\
\text { potential } \\
\text { preferential } \\
\text { pathways, high } \\
\text { conductivity } \\
\text { zones }\end{array}$ & None & $\begin{array}{l}\text { Used as } \\
\text { overlay. } \\
\text { This } \\
\text { indicator } \\
\text { was } \\
\text { buffered } \\
\text { with a } \\
\text { setback }\end{array}$ \\
\hline $\begin{array}{l}\text { Appropriateness } \\
\text { of including } \\
\text { folded strata as } \\
\text { an indicator }\end{array}$ & 11 & 0 & 7.00 & 7.00 & 7.00 & 2.41 & 3.00 & 10.00 & $\begin{array}{l}\text { Affects } \mathrm{K} \text {, folds are } \\
\text { more related to } \\
\text { surface outcrop, } \\
\text { potential for up- } \\
\text { dip frack fluid } \\
\text { migration }\end{array}$ & $\begin{array}{l}\text { This is mainly outside } \\
\text { the area of interest (for } \\
\text { oil and gas mining } \\
\text { [extraction]) }\end{array}$ & $\begin{array}{l}\text { Used as } \\
\text { overlay. } \\
\text { This } \\
\text { indicator } \\
\text { was } \\
\text { buffered } \\
\text { with a } \\
\text { setback }\end{array}$ \\
\hline $\begin{array}{l}\text { Appropriateness } \\
\text { of including } \\
\text { EC as an } \\
\text { indicator }\end{array}$ & 11 & 0 & 6.82 & 7.00 & 10.00 & 2.82 & 1.00 & 10.00 & $\begin{array}{l}\text { Useful under } \\
\text { normal } \\
\text { circumstances, } \\
\text { but uncertain in } \\
\text { terms of confined } \\
\text { aquifers, may be } \\
\text { critical to sole } \\
\text { source users }\end{array}$ & $\begin{array}{l}\text { Local variations, } \\
\text { spatially and in depth } \\
\text { may be important. } \\
\text { Risky to indicate some } \\
\text { areas as low } \\
\text { vulnerability based on } \\
\text { high EC, as } \\
\text { desalination becomes } \\
\text { cheaper, salty water } \\
\text { may become more } \\
\text { economical to use as } \\
\text { potable source }\end{array}$ & Not used \\
\hline $\begin{array}{l}\text { Appropriateness } \\
\text { of "aquifer } \\
\text { yield" as an } \\
\text { indicator }\end{array}$ & 11 & 0 & 6.64 & 6.00 & 10.00 & 3.58 & 1.00 & 10.00 & $\begin{array}{l}\text { Important to protect } \\
\text { high-yield } \\
\text { aquifers, valuable } \\
\text { indicator for near } \\
\text { surface } \\
\text { transmissivity, } \\
\text { surrogate for K }\end{array}$ & $\begin{array}{l}\text { Refers only to uppermost } \\
\text { aquifers, national } \\
\text { mapping can mask } \\
\text { local variability } \\
\text { (alluvial channels, } \\
\text { fracture zones). Even } \\
\text { low transmissivity } \\
\text { zones may be vital sole } \\
\text { source aquifers, no less } \\
\text { important to protect }\end{array}$ & Not used \\
\hline
\end{tabular}


the most relevant, publically available, regional groundwater vulnerability indicator for UOG extraction in the South African case. This indicator may also be of relevance for other countries who want to indicate their groundwater vulnerability to UOG extraction, although it may need to be adapted for the country-specific conditions.

\section{Overlay indicators}

Identified geological structures were included as overlay indicators because the potential exists that these features may increase hydraulic connectivity between deep strata and more shallow formations (Broomfield 2012), but they are also relevant for shallow aquifer contamination from the surface. Experts also supported the inclusion of these indicators (Table 1). Lastly, the geological structures are also important in cases where the geological structures may be intersected and stimulated by fracturing, possibly resulting in fluid migration (Cook et al. 2013; Frogtech 2013). Certain indicators that were suggested by experts in addition to the questionnaire indicators under structures that may indicate increased hydraulic connectivity between deep strata and shallow formations include sills and sill margins, undifferentiated lineaments and thermal springs. These additional indicators were included under structures on the map. Setback rules were used for these structures to ensure better protection of aquifers. This will be discussed in the indicator classification section.

The indicators "Yield" and "EC" were not included as separate sensitivity indicators because many experts felt that yield and EC do not indicate intrinsic aquifer vulnerability. Although the mode for these indicators was 10, responses on the appropriateness of these indicators ranged from 1 to 10, illustrating a large variance. The reasons cited for not including these as indicators of sensitivity to vulnerability were more important than the fact that it received good quantitative support for inclusion in the vulnerability map. Reasons ranged from the fact that poor-quality groundwater and low-yielding aquifers are also socioeconomically important and thus sensitive, especially if these are the only sources of water, a view that is echoed by researchers such as Robins et al. (2007). There was also the matter that poor-quality water can also be treated to potable standards.

Instead of using yield and EC as indicators, groundwater use as an indicator of socio-economic importance was included under the socio-economics map. Yield and EC information as associated with boreholes were, however, indicated on the interactive vulnerability map in the "Boreholes" map overlay. This information is based on the most recent field measurements from the National Groundwater Archive (DWA 2014a). Experts frequently mentioned boreholes for inclusion on the interactive vulnerability map (during both the first and second round of questionnaires). Information on boreholes that experts wanted on the map included mapping boreholes with poor borehole construction, as well as water production boreholes. Although "boreholes" are more relevant on a local scale and is a monitoring indicator, the researcher eventually decided to indicate the positions of boreholes that are available on the NGA. The associated borehole information, such as the identifier number, the data owner, coordinates, other numbers, $\mathrm{pH}$, temperature, EC, yield, water use, borehole depth, casing information, and water level information, where available, is indicated if a user clicks on a specific borehole in the "Boreholes" overlay. The aim of the borehole information overlay layer is to provide additional reconnaissance information for further detail studies. Setback rules may be applied to water production boreholes, but were not performed for this map, due to the fact that information such as the productivity and use of the boreholes may change (some boreholes may cease to yield productive volumes and may be closed while previously unused boreholes with lower yields or poor water quality may subsequently be used as water production boreholes). It is extremely important that updated borehole information should be indicated in local-scale studies at the time when an oil and gas exploration licence is sought. When plotting water production boreholes, care should be taken to confirm the exact positions of these boreholes. Accurate borehole positions, borehole construction, water use volumes and water quality would be extremely important during monitoring for UOG extraction.

Additional overlays on the groundwater mapping theme include the shapefiles on areas where prospecting and mining, as well as petroleum exploration and production, is legally prohibited (Holness 2013), subterranean groundwater control areas (DWA 2014b), borehole information from the National Groundwater Archive (DWA 2014a), Vegter's groundwater regions (DWA 2013) rivers (Nel et al. 2011), water management areas (DWA 2014b), roads (Openstreetmap 2014) and technical cooperation permit (TCP) and exploration right (ER) areas (PASA 2014). These overlays were indicated by experts as useful during reconnaissance and were thus included as overlays.

\section{Indicator classification and identification of buffer zones for the geological structures overlay map}

Aquifer vulnerability as updated during the Groundwater Resource Assessment Phase II (GRAII) project (DWAF 2005) is an accepted representation of South Africa's regional groundwater vulnerability and was used as a base layer to indicate regional groundwater vulnerability to UOG extraction. Various surface activities that form part of the UOG extraction process can contribute to shallow 
aquifer contamination and vulnerable shallow aquifer areas should thus be protected.

Selected aquifer vulnerability classes were tested via expert input via Questionnaire 2. It was classed into low $(<90)$, moderate $(90-140)$ and high $(>140)$ classes by the GRAII project. The low and high classes are further subdivided into very low $(<50)$ and very high $(>160)$ classes to derive the 5 classes. A map of these classifications can be seen in Fig. 1.

Sixty per cent of the respondents supported the aquifer vulnerability classification fully. Of those who did not support it fully, reasons were not related to the classification, but were related to the use of the indicator. The concern of the experts who did not support it fully was that this indicator only indicates shallow groundwater vulnerability, which according to these experts, is not a concern during UOG extraction. However, land surface impacts from UOG extraction, especially CBM extraction processes, will impact severely on shallow groundwater resources. The use of the DRASTIC approach to perform a basin-wide (regional) assessments of shallow groundwater vulnerability from CBM extraction in Australia was recently illustrated by Navi et al. (2017) and Rivard et al. (2014). One expert expressed the opinion that there must be a separate set of vulnerability descriptions for impacts generated at the source of shale oil and gas (deep seated shale horizons), and the methodologies that are applied to develop UOG resources on the land surface (hydraulic fracturing and borehole construction works).

Geological structures such as dykes, kimberlites and diatremes, faults, shear zones, and fold axes from the 1:1,000,000 South African geological map (CGS 2013) were all included as overlays on top of the vulnerability base layer as areas where more caution should be exercised. The flagging of these structures was a first attempt to address the vulnerability aspects of impacts generated at depth (as highlighted above by the one respondent). Buffer zones were assigned and can operate as "setback rules" or as zones within which a more cautious approach should be followed.

Buffer zones were applied to these structures due to the uncertainty of the morphology of these structures at depth. These buffer zones are based in part on mapping work done for the Karoo Groundwater Atlas (Rosewarne et al. 2013). The buffer zones indicate zones within which more care should be taken during UOG exploration and extraction. The applied buffer zones, which were tested for appropriateness via expert input during Questionnaire 2, can be seen in Table 2. Eighty per cent of respondents supported the buffer zones as identified by the researcher; however, some of these buffer zones have been adjusted based on input and comments from certain experts. A map of these structures, with buffer zones, can be seen in Fig. 2 .
Final interactive groundwater vulnerability map for UOG extraction

The spatial datasets of the groundwater theme of the interactive UOG extraction vulnerability map can be explored and interrogated by zooming, panning, and querying. When the user clicks on a specific entity to query it, information is displayed in an information box.

The functionality of the interactive groundwater vulnerability map for UOG extraction and the types of queries that can be lodged are illustrated in Fig. 3. Here, the map has been zoomed to a prospective UOG extraction area, and it has been queried at the point indicated on the map by the red arrow. In this example, the DRASTIC groundwater vulnerability base layer at the query point on the map is rated as medium, meaning that precautionary measures should be taken to protect the shallow groundwater resources in this area. At this point on the map, there is also a dolerite dyke that has been buffered with $500 \mathrm{~m}$. UOG companies should in this example, therefore, avoid any UOG extraction activities within $500 \mathrm{~m}$ of this geological structure, to minimise the risk of groundwater contamination from UOG stimulation wells or from possible associated UOG extraction wastewater spillages, via this geological structure. At this point, an ephemeral river and a groundwater supply borehole are also present, which would have to be avoided in order to minimize the risk of groundwater contamination at the borehole and also contamination to groundwater resources via surface watergroundwater interaction at the river.

The type of queries which can be lodged on the interactive map may assist regulators and policymakers in South Africa in deciding how UOG extraction should be regulated in certain sensitive areas before UOG extraction is allowed, in order to proactively protect groundwater resources during UOG extraction. It could also prove a valuable tool for local-scale environmental impact assessments. Ideally, this map should be updated with real-time monitoring data from UOG operations, when such operations are taking place, to extend the usefulness of the interactive map and to assist in proper natural resource protection.

\section{Conclusion and policy recommendations}

\section{The importance of linked regional baseline vulnerability mapping and groundwater monitoring for protection of valuable and vulnerable groundwater resources}

In terms of groundwater, the unique features in South Africa in terms of complex geology where dolerite dykes 


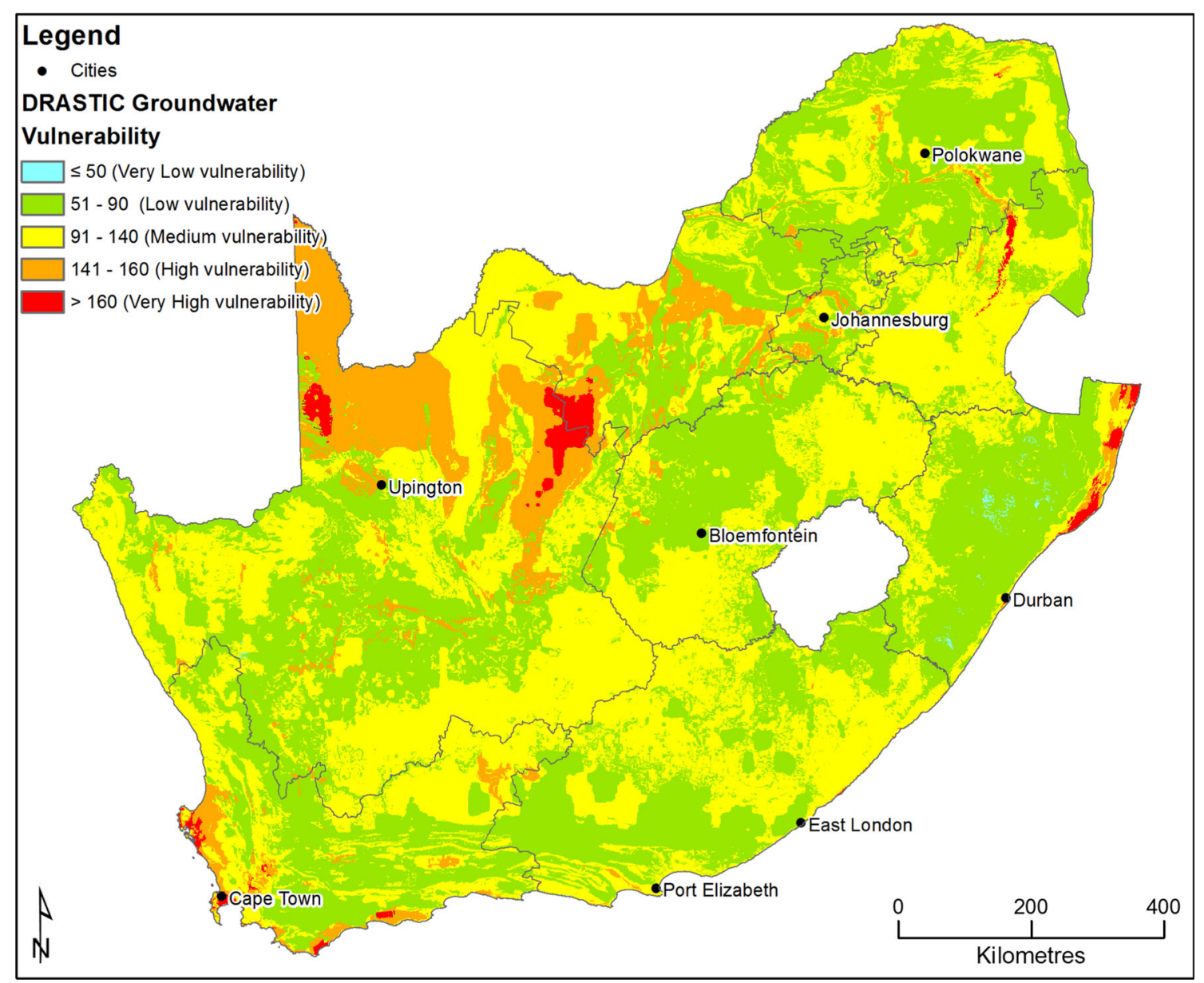

Fig. 1 GRAII Drastic aquifer vulnerability base layer for South Africa (DWAF 2005)

intruded the native country rocks (Esterhuyse et al. 2014; Hobbs et al. 2016), the complex fractured rock aquifer systems (Esterhuyse et al. 2014; Steyl et al. 2012), and the limited water availability (Esterhuyse et al. 2016b; Hobbs et al. 2016) warrant a cautious approach regarding water resources in our endeavour to extract UOG, since the environmental and socio-economic consequences linked to impacts of UOG extraction on water resources may be much more severe than in other countries where UOG is currently extracted. Brantley et al. (2014) stated that firm conclusions on water resource impacts are hampered by a lack of information about the location and timing of incidents, not releasing water quality data related to specific incidents due to liability or confidentiality agreements; the sparseness and accuracy of sample and sensor data for the analytes of interest, and the presence of pre-existing water quality impacts that hampers determining impacts from UOG extraction. This illustrates the importance of proper baseline monitoring that is linked to baseline vulnerability mapping.

Most international vulnerability maps for UOG extraction have been produced retrospectively, after UOG operations have already started, and do not represent baseline maps. Baseline monitoring and developing related baseline vulnerability maps could provide direct input into an adaptive management approach by reducing uncertainty in our understanding of the effects of UOG extraction and risks to natural resources and humans, while providing an impartial scientific base to support the sustainable use of resources in UOG extraction areas. Countries that are still planning to embark on UOG extraction, thus, have the unique opportunity to address data needs and perform crucial baseline vulnerability mapping before UOG extraction starts.

While baseline water quality mapping before the start of UOG exploration is now becoming international standard practice (Jackson et al. 2013), Rivard et al. (2014) stress the importance of (1) common databases, methodologies, and deliverables so that final results, tools, maps, and cross sections will be comparable and/or have similar meanings, and (2) the mandatory participation of regional organisations to ensure that what is being studied is relevant to the region, and that knowledge, maps, and tools are transferred to users. They also noted the need for a transfer of scientific 
Table 2 Buffer zones for geological structures

\begin{tabular}{|c|c|c|}
\hline Indicator & Buffer zone used in Fig. 2 & Reasons for using these buffer zones \\
\hline Dykes & $\begin{array}{l}500 \mathrm{~m} \text { from centre line of } \\
\text { structure }\end{array}$ & $\begin{array}{l}250 \mathrm{~m} \text { buffer zones were suggested by Rosewarne et al. (2013); however, one expert } \\
\text { suggested } 500 \mathrm{~m} \text { to cater for the possibility of reactivated dykes (where a series of } \\
\text { several deep fractures may run along the dyke). Another expert stated that if a } 250 \mathrm{~m} \\
\text { buffer zone is applied, it should be applied from the rim of the structure and not from the } \\
\text { centre line. CGS data on dykes is, however, only available as lineaments and thus a } \\
500 \mathrm{~m} \text { buffer zone was applied }\end{array}$ \\
\hline $\begin{array}{l}\text { Kimberlites and } \\
\text { diatremes }\end{array}$ & $\begin{array}{l}500 \mathrm{~m} \text { radius from centre } \\
\text { point of structure }\end{array}$ & $\begin{array}{l}100 \mathrm{~m} \text { consideration zones were suggested (Rosewarne et al. 2013); however, kimberlites } \\
\text { have complex associated emplacement models (Field and Scott-Smith 1999; Skinner } \\
2009 \text { ) and the surface and underground morphology of these structures may be quite } \\
\text { large and varied (Field and Scott-Smith } 1999 \text {; Woodford and Chevallier 2002), with } \\
\text { surface outcrop morphology varying from } 1 \text { to }>15 \text { ha (Skinner 2009). The researcher } \\
\text { suggested a } 250 \mathrm{~m} \text { buffer zone from the centre point of the structure; however, one } \\
\text { expert stated that the possibility of radial structures running from these features may still } \\
\text { exist } 250 \mathrm{~m} \text { from the feature and suggested a } 500 \mathrm{~m} \text { buffer. Another expert stated that } \\
\text { buffers should be applied from the rim of the structure and not from the centre point-a } \\
500 \mathrm{~m} \text { buffer zone is thus deemed more appropriate }\end{array}$ \\
\hline $\begin{array}{l}\text { Faults, shear zones, } \\
\text { and fold axis }\end{array}$ & $\begin{array}{l}1000 \mathrm{~m} \text { from centre line of } \\
\text { structure }\end{array}$ & $\begin{array}{l}250 \mathrm{~m} \text { buffer was suggested by Rosewarne et al. (2013); however, one expert stated that } \\
\text { unless these features are mapped in detail, a buffer of } 250 \mathrm{~m} \text { is too narrow. Fold axes } \\
\text { must be treated separately as their fold axis limb angles should be considered which may } \\
\text { push the distance to several kilometres. A buffer of } 1000 \mathrm{~m} \text { is thus applied based on the } \\
\text { buffer suggestion by this expert }\end{array}$ \\
\hline Dolerite sills & $\begin{array}{l}250 \mathrm{~m} \text { from rim of surface } \\
\text { outcrops }\end{array}$ & $\begin{array}{l}\text { Morphology of sill surface outcrops may not be representative of underground morphology } \\
\text { (Rosewarne et al. 2013). The researcher suggested the applying the precautionary } \\
\text { principle with a buffer zone of } 250 \mathrm{~m} \text { from the rim of these structures. One expert stated } \\
\text { that a differentiated approach should be used here, since transgressing sills are complex } \\
\text { and a dislodged contact may reach all along the contact zones, which might stretch for } \\
\text { kilometres. Bedding plane sills may offer a high security to percolating fluids/gases from } \\
\text { the shale gas source. A buffer of } 250 \mathrm{~m} \text { is used here in lieu of more detailed data and to } \\
\text { adhere to the precautionary principle }\end{array}$ \\
\hline $\begin{array}{l}\text { Undifferentiated } \\
\text { structures }\end{array}$ & $\begin{array}{l}1000 \mathrm{~m} \text { from centre line of } \\
\text { structure }\end{array}$ & $\begin{array}{l}\text { Due to unknown structure type and morphology, the researcher in the questionnaire } \\
\text { suggested applying the precautionary principle with a } 250 \mathrm{~m} \text { buffer zone. One expert } \\
\text { stated that depending on the geometry, shale oil and gas exploration and extraction } \\
\text { should be limited near these features. Unless detailed geophysical investigations have } \\
\text { been conducted, the buffer should be } 1000 \mathrm{~m} \text {. Concerns have again been raised by one } \\
\text { expert regarding applying buffer zones from the rims of these structures, thus a } 1000 \mathrm{~m} \\
\text { buffer zone may be more appropriate }\end{array}$ \\
\hline Thermal springs & $\begin{array}{l}1000 \mathrm{~m} \text { radius from } \\
\text { coordinate position }\end{array}$ & $\begin{array}{l}1000 \mathrm{~m} \text { consideration zones are suggested in Rosewarne et al. (2013). Thermal springs are } \\
\text { associated closely with deeper geological structures (Kent 1969), usually with faults and } \\
\text { folds (Olivier et al. 2011), and thermogenic methane associated with some thermal } \\
\text { springs indicate definite deep connections (Talma and Esterhuyse 2013). The researcher } \\
\text { suggested a } 500 \mathrm{~m} \text { radius as a } 1000 \mathrm{~m} \text { may be too stringent, but one expert stated that } \\
\text { springs get their water from recycling shallow water sources and indications are that this } \\
\text { geothermal water may come from } 1000 \mathrm{mbgl} \text {. A } 1000 \mathrm{~m} \text { radius buffer zone is thus } \\
\text { suggested by the experts and was applied }\end{array}$ \\
\hline
\end{tabular}

information to the stakeholders. In this regard, the interactive vulnerability map aims to address the issues of common databases to ensure comparable maps and common interpretations of results, as well as the transfer of scientific information to stakeholders (government, consultants, and academia). The Academy of Science of South Africa (ASSAF 2016) also stated that technology, scientific studies, and regulations must be developed coherently in South Africa to ensure sustainable development during UOG extraction. Such regulations should include mandatory participation of the relevant stakeholders.
The interactive vulnerability map that was developed for South Africa has assisted practitioners in performing the strategic environmental assessment for shale gas development in the Karoo (Hobbs et al. 2016), but may also in future be useful during assessments of water use licence applications, UOG extraction permit applications and EIAs, since this map presents the relevant vulnerability information in a central location and in a comprehensible format. Decision-makers usually struggle with making decisions on licences since all the relevant information is not easily accessible in one central location. International 


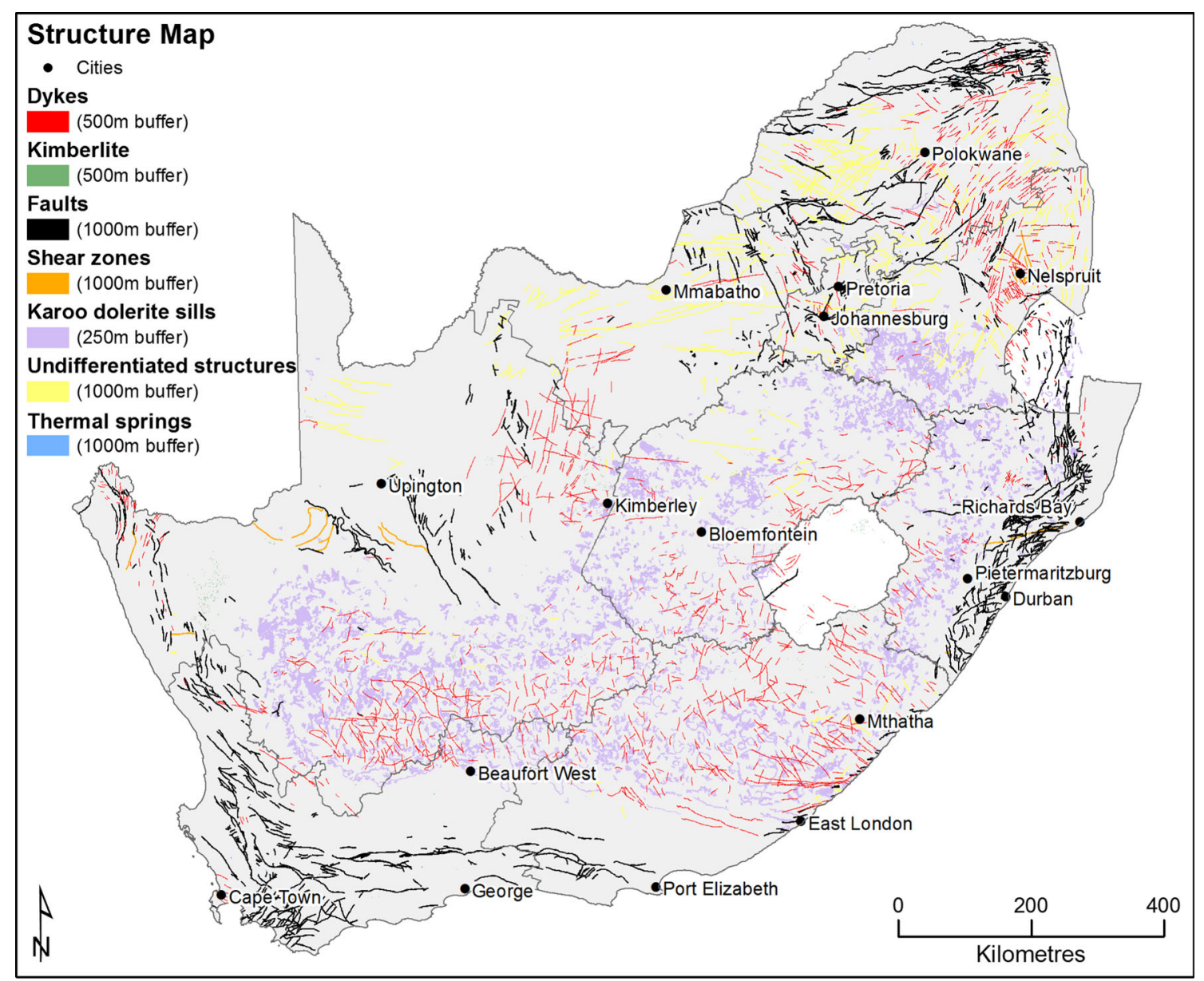

Fig. 2 Map of South Africa indicating 1:1,000,000 geological structures with its buffer zones (CGS 2013)

experts also commented on the need to have a centralised database for UOG extraction and its related activities. In order to maintain an updated centralised database, public disclosure of fracking data must be required to ensure that policymakers, researchers, industry, and other stakeholders have access to comprehensive and reliable information on the localities of active and abandoned wells, as well as related data that is important for the protection of natural resources and human health (Konschnik and Dayalu 2016).

\section{The critical need for local shallow and deep groundwater resources assessment and aquifer classification during the EIA phase}

The risk of groundwater contamination from UOG exploration and extraction is a major societal concern, not only in South Africa, but also in other countries that rely extensively on groundwater resources for providing drinking water or for agricultural or industrial use. Even though the South African interactive groundwater vulnerability map for UOG extraction is a useful start to protecting groundwater resources in South Africa, it only provides a regional baseline of groundwater conditions and sensitivities. Intensive local-scale groundwater resource assessment and aquifer classification are therefore required in the UOG extraction target areas before exploration even starts. Such studies would typically be executed during the EIA phase.

Aspects that would need to be investigated to fill current knowledge gaps regarding the impact of UOG extraction on groundwater resources include field testing to determine potential mechanisms and pathways by which hydrocarbon gases, reservoir fluids, and fracturing chemicals might potentially invade and contaminate useable groundwater (Jackson et al. 2013). Since groundwater decontamination is difficult, or nearly impossible, it is also essential to evaluate exploration and production conditions that would prevent or at least minimize risks of groundwater contamination (Lavoie et al. 2014).

Lavoie et al. (2014) also state that, despite the fact that groundwater resources may be relatively well characterised in some regions, there is currently no recognised method to evaluate the vulnerability or risks to aquifers resulting from hydrocarbon industry operations carried out at great depths. 


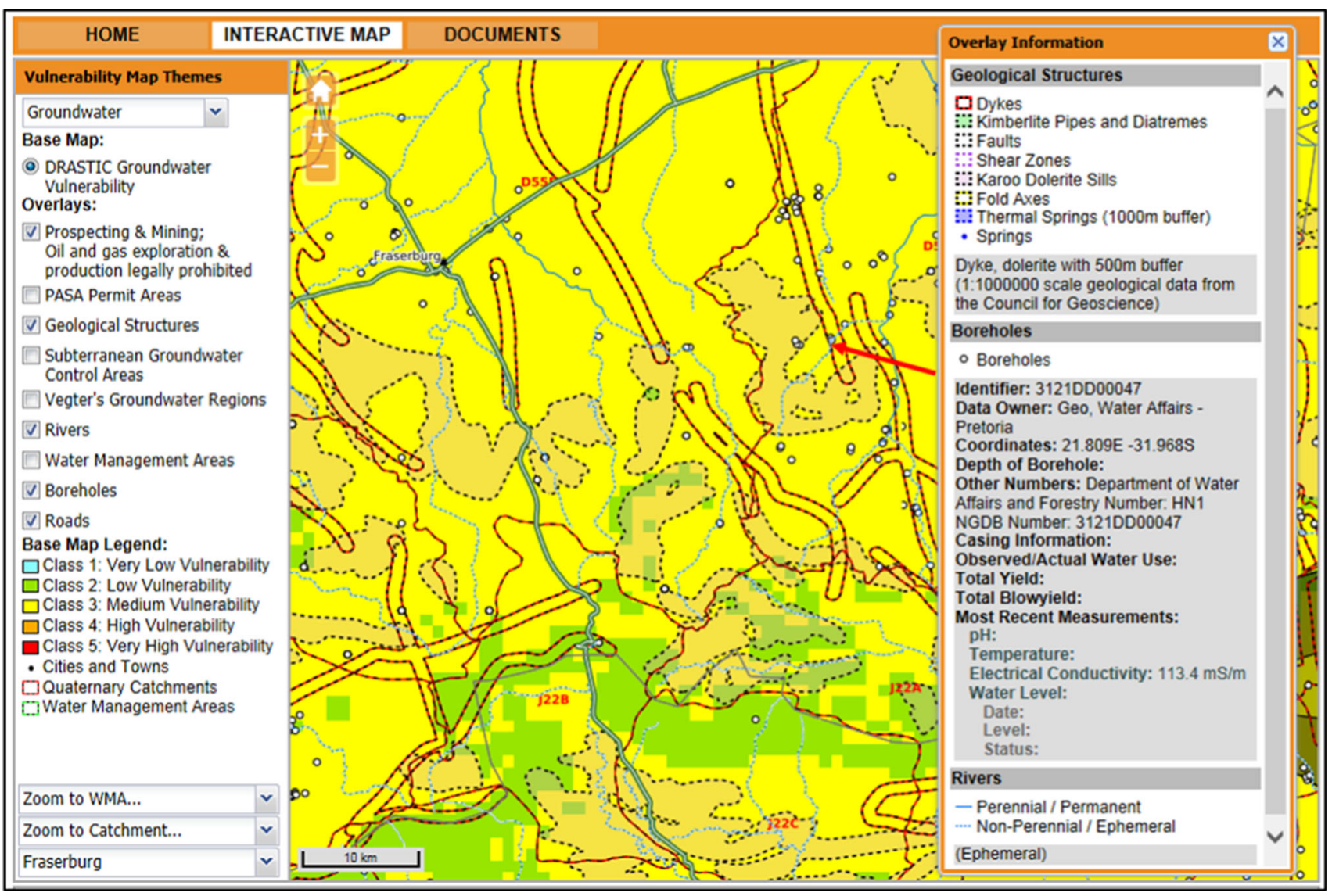

Fig. 3 Example of the interactive groundwater vulnerability map for UOG extraction zoomed in on a specific area and queried for information

In the South African interactive groundwater vulnerability map, geological structures were included as a map overlay in an attempt to address this issue on a regional scale. However, there is a need to perform detailed local assessments of the deeper geology and geohydrology linked with detailed fracture mapping if we want to effectively protect groundwater resources during UOG extraction.

South Africa recognised this concern and thus requires in their "Regulations for petroleum exploration and production" (RSA 2015), during EIA assessments, an assessment of the conditions below ground, where the geology and geohydrology of the target area must be assessed and a report submitted to the designated agency for approval prior to well design and drilling (i.e. prior to exploration). Information that should be contained in the report includes stratigraphy to understand structural complexity, hydrogeochemical character of the target formations, information on porosity, permeability, naturally occurring fissures and fractures, the presence and morphology of dolerite, kimberlite and other tectonic structures and a model of fluid migration in the geological formations. The South
African Department of Water and Sanitation, the custodian of the country's water resources, is in the process of drafting regulations to specifically protect water resources during UOG extraction, where these aspects will also be addressed. In the Water resources chapter of the strategic environmental assessment (SEA) for shale gas development (Hobbs et al. 2016), conservative setbacks from sensitive aquifers, groundwater features, and geological structures have been recommended in the absence of detailed local field information. The SEA also requires detailed field assessments during the EIA phase to augment current geohydrological and geological information that is mostly only available on a shallow depth and regional scale for groundwater resources and only on a regional scale for geology.

\section{The importance of developing an updatable database during UOG extraction to update the groundwater vulnerability map}

While a vulnerability map that shows vulnerable entities may be useful to regulators, it is recommended that the 
vulnerability map be linked to an active South African database, much like the Fracktracker database, an extensive interactive map that shows information on where UOG extraction takes place by showing well site, gas pipeline, and shale gas deposit localities, and where available, information on volumes of water and chemicals used and wastewater recovered (Fracktracker Alliance 2016). The interactive groundwater vulnerability map for UOG extraction does not currently show localities of fracking activities since UOG extraction has not started yet in South Africa and only shows the potential areas where UOG extraction may take place (the PASA permit areas). The information on permit areas, however, needs to be updated regularly, and when exploration and extraction of UOG resources occur, information on well pad localities, volumes of water and chemicals used, as well as related monitoring information and related infrastructure development, needs to be included on such an interactive map. Such information would also need to be regularly updated.

Currently, components of the vulnerability map that were developed during this project have been taken up for use in the SEA of planned shale gas exploration in the central Karoo region (Scholes et al. 2016). It would, however, be very useful for South Africa to develop vulnerability maps that show the vulnerability (sensitivity) of natural resources and socio-economic aspects that also includes UOG extraction activities on a linked live database, such as the Fracktracker maps. Such a tool would assist decision-makers with resource protection strategies, both in countries still planning to embark on UOG extraction and countries which already are extracting UOG resources. Wang et al. (2011) describe an updated approach to groundwater vulnerability mapping during UOG extraction, where both natural geological and human factors are taken into account. In their model, the natural geological factors include the following: oil-gas deposit quantity and size, distances from oil-gas deposits to confined aquifer and aquifer media characteristics, distribution of faults and filled media characteristics, and permeability and continuity of the aquifer media. The human activities factors include the number and distribution of oil wells, the number and distribution of water input wells, and the exploitation quantity of groundwater. Of the above factors, only some indicators are known at this stage in South Africa, while UOG exploration and extraction related indicators will only become available once UOG exploration and extraction starts. However, since this information is so important for updating groundwater vulnerability maps, it would have to be properly regulated to ensure that such data is reported to government by UOG companies and is properly monitored also properly archived (Hobbs et al. 2016).
Acknowledgements The Water Research Commission, South Africa, is thanked for providing funding for this research (Grant No. K5-2149).

Open Access This article is distributed under the terms of the Creative Commons Attribution 4.0 International License (http://crea tivecommons.org/licenses/by/4.0/), which permits unrestricted use, distribution, and reproduction in any medium, provided you give appropriate credit to the original author(s) and the source, provide a link to the Creative Commons license, and indicate if changes were made.

\section{References}

Academy of Science of South Africa (ASSAF) (2016) South Africa's technical readiness to support the shale gas industry. http:// research.assaf.org.za/handle/20.500.11911/14

Aller L, Bennett T, Lehr JH, Petty RJ, Hackett G (1987) DRASTIC: a standardised system for evaluating groundwater pollution potential using hydrogeologic settings. US-EPA Report 600/2-87-035

Brantley SL, Yoxtheimer D, Arjmand S, Grieve P, Vidic R, Pollak J, Llewellyn GT, Abad J, Simon C (2014) Water resource impacts during unconventional shale gas development: the Pennsylvania experience. Int J Coal Geol 126:140-156. doi:10.1016/j.coal. 2013.12.017

Brittingham MC, Maloney KO, Farag AM, Harper DD, Bowen ZH (2014) Ecological risks of shale oil and gas development to wildlife, aquatic resources and their habitats. Environ Sci Technol 48(19):11034-11047. doi:10.1021/es5020482

Broomfield M (2012) Support to the identification of potential risks for the environment and human health arising from hydrocarbons operations involving hydraulic fracturing in Europe (Report No. ED57281-17c). http://ec.europa.eu/environment/integration/ energy/pdf/fracking\%20study.pdf

Brown D (2009) Good Practice Guidelines for Indicator Development and Reporting. In: Paper presented at 3rd OECD World Forum on 'Statistics, knowledge and policy' charting progress, building visions, improving life, Busan, Korea, 27-30 Oct 2009. https:// www.oecd.org/site/progresskorea/43586563.pdf

Cook C, Beck V, Brereton D, Clark R, Fischer B, Kentish S, Toomey J, Williams J (2013) Engineering energy: unconventional gas production. A study of shale gas in Australia. Final report. Australian Council of Learned Academies

Council for Geoscience (CGS) (2013) 1:1,000,000 geological structure data. Council for Geoscience

Department of Water Affairs (DWA) (2013) Data on subterranean groundwater control areas and Vegter's groundwater regions. Department of Water Affairs, Pretoria

Department of Water Affairs and Forestry (DWAF) (2005) Groundwater resource assessment phase II. Project 4. methodology for classification. Final report. Department of Water Affairs, Pretoria

DWA (2014a) Data from the national groundwater archive. Department of Water Affairs, Pretoria

DWA (2014b) Data on new water management areas. Department of Water Affairs, Pretoria

Esterhuyse S, Avenant MF, Watson M, Redelinghuys N, Kijko A, Glazewski J, Plit LA, Kemp M, Smit A, Sokolic F, Vos AT, Reynolds D, von Maltitz M, van Tol J, Bragg C, van Soelen B, Ouzman S (2014) Development of an interactive vulnerability map and monitoring framework to assess the potential environmental impact of unconventional oil and gas extraction by means of hydraulic fracturing. WRC Report No. 2149/1/14. Water Research Commission, Pretoria 
Esterhuyse S, Avenant M, Redelinghuys N, Kijko A, Glazewski J, Plit L, Kemp M, Smit A, Vos AT, Williamson R (2016a) A review of biophysical and socio-economic effects of unconventional oil and gas extraction-implications for South Africa. J Environ Manag 184(2):419-430

Esterhuyse S, Redelinghuys N, Kemp M (2016b) Unconventional oil and gas extraction in South Africa: water linkages within the population-environment-development nexus and its policy implications. Water Int Spec Ed Out Mines Out Site Water Leg Conv Min 41(3):409-425. doi:10.1080/02508060.2016. 1129725

Field M, Scott-Smith BH (1999) Contrasting geology and nearsurface emplacement of kimberlite pipes in Southern Africa and Canada. In: Dawson JB (ed) Proceedings of 7th international kimberlite conference, vol 1. Red Roof Design, Cape Town, pp 214-237

Fracktracker Alliance (2016) Oil and gas information by location. http://www.fractracker.org/map/

Freyman M (2014) Hydraulic fracturing and water stress: water demand by the numbers. CERES. https://www.ceres.org/ resources/reports/hydraulic-fracturing-water-stress-water-demandby-the-numbers/view

Frogtech (2013) Geological risks of shale gas in Australia. Project AAS 801. Frogtech Pty Ltd., Australia

General Accounting Office (GAO) (2010) Superfund EPA's estimated costs to remediate existing sites exceed current funding levels, and more sites are expected to be added to the national priorities list. Commissioned report to USA Congress. http://www.gao. gov/products/GAO-10-380

Grant L, Chrisholm A (2014) Shale gas and water: an independent review of shale gas exploration and exploitation in the UK with a particular focus on the implications for the water environment. The Chartered Institution of Water and Environmental Management (CIWEM). www.ciwem.org/shalegas

Harvey A, Hinkel J, Horrocks L, Klein R, Lasage R, Hodgson N, Sajwaj T, Benzie M (2009) Preliminary assessment and roadmap for the elaboration of climate change vulnerability indicators at regional level. Unpublished, available at DG ENV. Final Report to the European Commission (Restricted Commercial, ED45669, Issue number 3)

Harvey A, Hodgson N, Benzie M, Winne S, Smithers R, Dresner S, Drummond P, Coleman C, Horrocks L, Harley M (2011) Provision of research to identify indicators for the Adaptation Sub-Committee (Issue number 3, June 2011). AEA Technology Plc. https://www.theccc.org.uk/archive/aws2/ASC\%202nd\% 20Report/ED56687\%20Final\%20Report\%20Issue\%203_130711. pdf

Hobbs P, Day E, Rosewarne P, Esterhuyse S, Schulze R, Day J, Ewart-Smith J, Kemp M, Rivers-Moore N, Coetzee H, Hohne D, Maherry A, Mosetsho M (2016) SGD Chapter 5: water resources. In: Scholes R, Lochner P, Schreiner G, Snyman-Van der Walt L, de Jager M (eds) Shale gas development in the Central Karoo: a scientific assessment of the opportunities and risks. Council for Scientific and Industrial Research, Pretoria. ISBN: 978-0-7988-5631-7

Holness S (2013) Informal discussion on the mining and biodiversity guideline data and provisioning of spatial data related to the mining and biodiversity guideline (personal communication)

Jackson RE, Gorody AW, Mayer B, Roy JW, Ryan MC, Van Stempvoort DR (2013) Groundwater protection and unconventional gas extraction: the critical need for field-based hydrogeological research. Groundwater 51(4):488-510. doi:10.1111/ gwat. 12074

Kent LE (1969) The Thermal waters in the Republic of South Africa. In: 23rd International geological congress, vol 19, pp 143-164
Konschnik K, Dayalu A (2016) Hydraulic fracturing chemicals reporting: analysis of available data and recommendations for policymakers. Energy Policy 88:504-514

Lavoie D, Rivard C, Lefebvre R, Séjourné S, Thériault R, Duchesne MJ, Ahad JM, Wang B, Benoit N, Lamontagne C (2014) The Utica Shale and gas play in southern Quebec: geological and hydrogeological syntheses and methodological approaches to groundwater risk evaluation. Int J Coal Geol 126:77-91

Lechtenböhmer S, Altman M, Capito S, Matra Z, Weindrorf W, Zittel W (2011) Impacts of shale gas and shale oil extraction on the environment and on human health. Report IP/A/ENVI/ST/2011-07, Policy Department (Economic and Scientific Policy), DirectorateGeneral for Internal Policies, European Parliament, Brussels, p 38

Maree K, Van der Westhuizen C (2010) Planning a research proposal. In: Maree K (ed) First steps in research. Pretoria, Van Schaik, pp 24-44

Nardo M, Saisana M, Saltelli A, Tarantola S (2005) Tools for composite indicators building. Report No. EUR 21682 EN. European Commission, Joint Research Centre, IPSC, Italy

National Research Council (NRC) (2012a) Induced seismicity potential in energy technologies. The National Research Council. Committee on induced seismicity potential in energy technologies, Committee on earth resources, Committee on geological and geotechnical engineering, Committee on Seismology and Geodynamics Board on Earth Sciences and Resources, Division on Earth and Life Studies. The National Academies Press, Washington, DC, p 240

Navi M, Nasiri S, Skelly C (2017) Basin-wide groundwater vulnerability assessment: a GIS based DRASTIC approach to the problem of coal seam gas extracted water

Nel JL, Driver A, Strydom WF, Maherry A, Petersen C, Hill L, Roux DJ, Nienaber S, Van Deventer H, Swartz E, Smith-Adao LB (2011) Atlas of freshwater ecosystems priority areas in South Africa: Maps to support sustainable development of water resources. WRC Report No. TT 500/11. Water Research Commission, Pretoria

NRC (2012b) Alternatives for managing the nation's complex contaminated groundwater sites. Committee on future options for management in the nation's subsurface remediation effort, Water Science and Technology Board, Division on Earth and Life Studies, National Research Council. The National Academies Press, Washington, DC, p 339 (prepublication copy)

Olivier J, Venter JS, Jonker CZ (2011) Thermal and chemical characteristics of hot water springs in the northern part of the Limpopo Province, South Africa. Water SA 79(4):427-436. doi:10.4314/wsa.v37i4.1

OpenStreetMap (2014) Roads data used for interactive vulnerability map. http://www.openstreetmap.org

Petroleum Agency of South Africa (PASA) (2014) Data for the TCP and ER areas. Provided by Petroleum Agency of South Africa, Cape Town

Preston B, Stafford-Smith M (2009) Framing vulnerability and coping capacity assessment: discussion paper. In: CSIRO climate adaptation flagship working paper no. 2. http://www.csiro.au/ org/ClimateAdaptationFlagship.html. Commonwealth Scientific and Industrial Research Organisation, Australia. https://research. csiro.au/climate/wp-content/uploads/sites/54/2016/03/2_WorkingPaper2 CAF_PDF-Standard.pdf

Republic of South Africa (RSA) (2015) Regulations for petroleum exploration and production under the Mineral and Petroleum Resources Development Act 28 of 2002. Government Gazette No. 38855

Rivard C, Lavoie D, Lefebvre R, Séjourné S, Lamontagne C, Duchesne M (2014) An overview of Canadian shale gas production and environmental concerns. Int $\mathrm{J}$ Coal Geol 126:64-76. doi:10.1016/j.coal.2013.12.004 
Robins NS, Chilton PJ, Cobbing JE (2007) Adapting existing experience with aquifer vulnerability and groundwater protection for Africa. J Afr Earth Sci 47(1):30-38

Rosewarne PN, Woodford AC, O'Brien R, Van Tonder G, Esterhuyse C, Goes M, Talma AS, Tredoux G, Visser D (2013) Karoo groundwater atlas volume 2. Karoo Groundwater Expert Group. http://gwd.org.za/sites/gwd.org.za/files/KGEG_Karoo\%20Ground water\%20Atlas\%20Volume\%202_Final_12Aug13_opt_opt.pdf

Russack W (2012) Got gas? Vulnerability to water contamination from fracking operations. http://sites.tufts.edu/gis/files/2013/11/ Russack_Will.pdf

Scholes R, Lochner P, Schreiner G, Snyman-Van der Walt L, de Jager M (eds) (2016) Shale gas development in the Central Karoo: a scientific assessment of the opportunities and risks. CSIR/IU/ 021MH/EXP/2016/003/A, ISBN: 978-0-7988-5631-7, Pretoria: CSIR. http://seasgd.csir.co.za/scientific-assessment-chapters/

Skinner EMW (2009) Developments in Kimberlite emplacement theory. The Southern African Institute of Mining and Metallurgy Diamonds-Source to Use 2009

Steyl G, Van Tonder GJ, Chevalier L (2012) State of the art: Fracking for shale gas exploration in South Africa and the impact on water resources. WRC Report. KV 294-11. Water Research Commission, Pretoria
Talma AS, Esterhuyse C (2013) Natural methane in the Karoo: Its occurrence and isotope clues to its origin. In: Proceedings of the 13th biennial groundwater division conference and exhibition

Vengosh A, Jackson RB, Warner N, Carrah TH, Kondash A (2014) A critical review of the risks to water resources from unconventional shale gas development and hydraulic fracturing in the United States. Environ Sci Technol 48(15):8334-8348. doi:10. 1021/es405118y

Wang Z, Wu Q, Zhang Y, Cheng J (2011) Confined groundwater pollution mechanism and vulnerability assessment in oilfields, North China. Environ Earth Sci 64(6):1547-1553

Williams J, Stubbs T, Milligan A (2012) An analysis of coal seam gas production and natural resource management in Australia. Report prepared for the Australian Council of Environmental Deans and Directors by John Williams Scientific Services. Canberra: ACEDD. http://aie.org.au/AIE/Documents/Oil_Gas_121114.pdf

Woodford AC, Chevallier L (2002) Hydrogeology of the Main Karoo basin: current knowledge and future research needs. Water Research Commission Report No. TT 179/02

Zoback M, Kitasei S, Copithorne B (2010) Addressing the environmental risks from shale gas Development (briefing paper 1). Worldwatch Institute, Washington, DC, p 18 